\title{
ANALISIS FAKTOR YANG MEMPENGARUHI TINGKAT INITIAL RETURN (STUDI PADA PERUSAHAAN NON KEUANGAN YANG TERMASUK DALAM INDEKS SAHAM SYARIAH INDONESIA YANG MELAKUKAN INITIAL PUBLIC OFFERING PADA TAHUN 2012-2016)
}

\author{
Dhedi Widihartanto \\ Mahasiswa Program Studi Ekonomi Islam-Fakultas Ekonomi dan Bisnis-Universitas Airlangga \\ Email: dhedi-w-11@feb.unair.ac.id
}

Ari Prasetyo

Departemen Ekonomi Syariah-Fakultas Ekonomi dan Bisnis-Universitas Airlangga Email: ari.prasetyo@feb.unair.ac.id

\begin{abstract}
:
linitial return is a positive return that investors get from underpricing conditions where there is a positive difference between the stock price in the secondary market and the stock price in the primary market on the first day of trading on the stock exchange. This research tries to examine the influence of financial information (Return on Equity, Debt to Equity Ratio, Total Asset Turnover and Price Earning Ratio) and non financial information (offered stock percentage and firm size) on initial return. The sample for this research are 44 non financial firm that include in Indonesia Sharia stock index (ISSI) during period of 2012-2016. This research use multiple regression as analytical methods. The results of this research indicate that financial information (Return on Equity, Debt to Equity Ratio, Total Asset Turnover, Price Earning Ratio) and non-financial information (offered stock percentage and firm size) provide no significant effect on the initial return either partially or simultaneously.
\end{abstract}

Key word: initial return, Return on Equity, Price Earning Ratio, firm size, underpricing.

\section{PENDAHULUAN}

Setiap perusahaan berupaya
untuk mengembangkan serta memperluas usahanya, hal tersebut dapat diwujudkan dengan melakukan ekspansi. Untuk melakukan ekspansi perusahaan memerlukan tambahan modal yang cukup besar. Dalam rangka memenuhi kebutuhan dana yang cukup besar tersebut, seringkali dana yang berasal dari dalam perusahaan saja tidak cukup. Salah satu alternatif pendanaan yang dapat digunakan oleh perusahaan yaitu dengan melakukan penerbitan saham baru yang dijual pada masyarakat melalui pasar modal atau yang biasa dikenal dengan go public. Dalam proses go public sebelum saham diperdagangkan di pasar sekunder (bursa efek) terlebih dahulu saham perusahaan yang go public dijual di pasar perdana (primary market) yang biasa disebut IPO (Initial Public Offering). Dengan dilakukannya penawaran umum perdana (IPO) oleh perusahaan, diharapkan akan memperbaiki prospek perusahaan. Fenomena yang seringkali timbul dari kegiatan IPO di seluruh dunia adalah terjadinya underpricing yang menunjukkan bahwa sebenarnya harga saham pada waktu penawaran perdana relatif lebih rendah dibanding pada saat diperdagangkan di pasar sekunder. Kondisi underpricingtersebut sangat merugikan perusahaan yang melakukan go public, karena dana yang diperoleh dari publik tidak maksimal namun kondisi underpricing yang terjadi di pasar saham perdana ternyata memberikan positive initial return pada investor. Dengan

${ }^{[1]}$ Jurnal ini merupakan bagian dari Skripsi Dhedi Widihartanto NIM 04114404 yang diuji pada tanggal 2 Juni 2017 
Widihartanto, et al/Jurnal Ekonomi Syariah Teori dan Terapan Vol. 5 No. 5 Mei 2018: 377-393; ANALISIS FAKTOR YANG MEMPENGARUHI TINGKAT INITIAL RETURN (STUDI PADA PERUSAHAAN NON KEUANGAN YANG TERMASUK DALAM INDEKS SAHAM SYARIAH INDONESIA YANG MELAKUKAN INITIAL PUBLIC OFFERING PADA TAHUN 2012-2016)

adanya posistive initial return investor akan

Berdasarkan uraian diatas maka mendapat keuntungan atas pembelian saham, Fenomena underpricing di Indonesia dapat dilihat dalam Tabel berikut ini:

Tabel 1

Fenomena underpricing yang terjadi di Indonesia Tahun 2012-2016

\begin{tabular}{|l|l|l|l|l|}
\hline No. & Kode & $\begin{array}{c}\text { Offering } \\
\text { Price }\end{array}$ & $\begin{array}{c}\text { Clossing } \\
\text { Price }\end{array}$ & $\begin{array}{c}\text { Initial } \\
\text { return }\end{array}$ \\
\hline 1 & GIAA & 475 & 750 & $57.89 \%$ \\
\hline 2 & STAR & 102 & 138 & $35.29 \%$ \\
\hline 3 & ALDO & 225 & 250 & $11.11 \%$ \\
\hline 4 & APII & 220 & 330 & $50.00 \%$ \\
\hline 5 & WSKT & 380 & 450 & $18.42 \%$ \\
\hline 6 & TAXI & 560 & 870 & $55.35 \%$ \\
\hline 7 & SRIL & 240 & 245 & $2.08 \%$ \\
\hline 8 & KRAH & 275 & 290 & $5.45 \%$ \\
\hline 9 & BLTZ & 3000 & 3400 & $13.33 \%$ \\
\hline 10 & LINK & 1600 & 2400 & $50.00 \%$ \\
\hline
\end{tabular}

Sumber: IDX (diolah)

Meskipun studi tentang kinerja saham perusahaan pada saat IPO telah banyak dilakukan, namun penelitian di bidang ini masih dianggap masalah yang menarik untuk diteliti karena hasil dari setiap penelitian yang tidak selalu konsisten, serta kebanyakan penelitian terdahulu lebih fokus pada informasi non keuangan. Padahal masih banyak variabel-variabel keuangan yang mungkin mempengaruhi underpricing maupun kinerja perusahaan setelah melakukan IPO yang belum diteliti. Hal inilah yang mendorong dilakukannya penelitian kembali di bidang ini. penelitian ini menggunakan informasi kevangan dan juga non keuangan sebagai variabel independen yang di duga mempengaruhi variabel dependen yang berupa initial return. Variabel informasi keuangan yang digunakan dalam penelitian ini adalah Return on Equity (ROE), Debt to Equity Ratio (DER), Total Asset Turnover (TATO) dan Price Earning Ratio (PER), sedangkan variabel non keuangan yang digunakan dalam penelitian ini adalah prosentase penawaran saham dan ukuran perusahaan.

\section{Rumusan Masalah}

1. Apakah ROE, DER, TATO,PER, Prosentase Penawaran Saham dan Ukuran Perusahaan berpengaruh secara simultan terhadap initial return pada saat IPO?

2. Apakah ROE, DER, TATO,PER, Prosentase Penawaran Saham dan Ukuran Perusahaan berpengaruh secara parsial terhadap initial return pada saat IPO?

Tujuan Penelitian

Berdasarkan rumusan masalah diatas maka tujuan penelitian ini adalah untuk menganalisis pengaruh ROE, DER, TATO, PER, Prosentase Penawaran Saham dan Ukuran Perusahaan terhadap initial return setelah IPO baik secara simultan maupun secara parsial.

II. LANDASAN TEORI

Pasar Modal 
Widihartanto, et al/Jurnal Ekonomi Syariah Teori dan Terapan Vol. 5 No. 5 Mei 2018: 377-393; ANALISIS FAKTOR YANG MEMPENGARUHI TINGKAT INITIAL RETURN (STUDI PADA PERUSAHAAN NON KEUANGAN YANG TERMASUK DALAM INDEKS SAHAM SYARIAH INDONESIA YANG MELAKUKAN INITIAL PUBLIC OFFERING PADA TAHUN 2012-2016)

Pasar modal merupakan suatu tempat bertemunya antara permintaan dan penawaran atas instrumen keuangan jangka panjang, baik dalam bentuk modal sendiri (stocks) maupun hutang (bonds) baik yang diterbitkan oleh pemerintah maupun oleh perusahaan swasta Husnan, 2009:3. Pasar modal merupakan pelengkap di sektor keuangan terhadap dua lembaga lainnya yaitu bank dan lembaga pembiayaan. Pasar modal memberikan jasanya yaitu menjembatani hubungan antara pemilik modal (investor) dengan peminjam dana (emiten) (Anoraga dan Pakarti, 2001:24).

\section{Initial Public Offerings (IPO)}

Initial public offerings (IPO) atau yang biasa dikenal dengan istilah go public adalah penawaran saham perdana kepada masyarakat yang dilakukan oleh suatu perusahaan. Keputusan perusahaan untuk menjadi perusahaan go public merupakan keputusan yang bukan tanpa perhitungan karena perusahaan dihadapkan pada beberapa konsekuensi yang menguntungkan maupun yang merugikan. Alasan dilakukan go public adalah karena dorongan atas kebutuhan modal (capital need). Perusahaan yang go public adalah perusahaan yang mengalami pertumbuhan yang pesat. Karena pertumbuhan yang pesat, perusahaan dituntut untuk mampu menyediakan dana untuk keperluan ekspansi dan untuk keperluan investasi baru. Melalui IPO perusahaan akan mendapatkan dana segar yang dapat digunakan sebagai modal untuk jangka panjang dan juga sangat berguna untuk mengembangkan perusahaan, membayar hutang dan tujuan-tujuan lainnya (Sitompul 2000:45.

\section{Initial return}

Initial return merupakan keuntungan yang diperoleh investor karena ada selisih harga saham yang dibeli di pasar perdana (saat IPO) dengan harga jual saham bersangkutan di hari pertama di pasar sekunder (Daljono, 2000). Initial return terjadi karena adanya perbedaan kepentingan antara emiten dan investor, yang mana emiten ingin memperoleh dana yang besar dan investor menginginkan return yang tinggi sehingga hal tersebut akan menimbulkan underpricing yakni timbulnya selisih positif antara harga saham di pasar sekunder dengan harga di pasar perdana atau biasa di sebut dengan Initial return. Bagi emiten, terjadinya underpricing tentunya akan membawa kerugian karena perusahaan tidak mendapat dana yang maksimal. Namun di sisi lain, emiten juga beranggapan bahwa underpricing dapat dijadikan strategi pemasaran untuk meningkatkan minat investor untuk membeli saham IPO dengan memberikan Initial return yang tinggi (Sulistio, 2005:89).Menurut Yasa (2005:345) Initial return dapat dihitung menggunakan rumus sebagai berikut:

$$
I R=\frac{\text { ClosingPrice }- \text { OfferingPrice }}{\text { OfferingPrice }} \times 100
$$


Widihartanto, et al/Jurnal Ekonomi Syariah Teori dan Terapan Vol. 5 No. 5 Mei 2018: 377-393; ANALISIS FAKTOR YANG MEMPENGARUHI TINGKAT INITIAL RETURN (STUDI PADA PERUSAHAAN NON KEUANGAN YANG TERMASUK DALAM INDEKS SAHAM SYARIAH INDONESIA YANG MELAKUKAN INITIAL PUBLIC OFFERING PADA TAHUN 2012-2016)

Keterangan:

$\mathrm{IR}=$ Initial return

Closing Price $=$ harga penutupan saham

hari pertama di pasar sekunder

Offering Price = harga penawaran perdana

Faktor-faktor yang mempengaruhi initial return

Return on Equity (ROE)

Return on Equity (ROE) adalah salah satu komponen penting dalam menentukan pertumbuhan earnings dan dividen, rasio ini mengukur kemampuan perusahaan menghasilkan laba berdasarkan modal saham tertentu (Hanafi dan Halim, 2005). Rasio ini dapat dihitung dengan rumus sebagai berikut:

ReturnOnEquity $=\frac{\text { Laba Bersih }}{\text { Ekuitas }}$

Semakin tinggi nilai ROE akan menunjukkan bahwa perusahaan mampu menghasilkan laba di masa yang akan datang dan laba merupakan informasi penting bagi investor sebagai pertimbangan dalam menanamkan modal.

\section{Debt to Equity Ratio (DER)}

Debt to Equity Ratio (DER) adalah salah satu dari rasio leverage. Nilai DER suatu perusahaan menunjukkan kemampuan perusahaan tersebut dalam memenuhi seluruh kewajibannya baik kewajiban jangka panjang maupun kewajiban jangka pendek. Menurut Weston dan Brigham (1993:209) Debt to Equity Ratio (DER) menunjukkan penggunaan hutang dalam rangka pembiayaan perusahaan, rasio ini mengukur seberapa jauh perusahaan dibiayai oleh hutang yang mencerminkan seberapa besar tingkat resiko perusahaan, yang akhirnya berdampak pada nilai (value) perusahaan. Rasio DER dapat dihitung dengan rumus sebagai berikut:

Debt to Equity ratio $=\frac{\text { Total Debt }}{\text { Total Equity }}$

Semakin tinggi nilai DER mengindikasikan bahwa struktur permodalan perusahaan lebih banyak memanfaatkan hutang - hutang relatif terhadap ekuitas.

\section{Total Asset Turnover (TATO)}

Total Asset Turnover merupakan salah satu rasio aktivitas, yaitu rasio yang menunjukkan kemampuan serta efisiensi perusahaan tersebut dalam menggunakan seluruh aktiva dalam menghasilkan volume penjualan tertentu, Semakin tinggi rasio TATO berarti semakin efisien penggunaan keseluruhan aktiva di dalam menghasilkan penjualan (Syamsuddin, 2010:32). Rasio TATO dapat di hitung dengan rumus sebagai berikut:

$$
\text { Total Asset Turnover }=\frac{\text { Nett Sales }}{\text { Total Assets }}
$$

Semakin tinggi nilai TATO maka semakin efisien suatu perusahaan dalam memanfaatkan aktiva yang dimilikinya.

\section{Price Earning Ratio (PER)}

Price Earning Ratio (PER) adalah rasio yang digunakan untuk mengukur seberapa tinggi para investor bersedia membayar atau menananmkan modal pada saham perusahaan, selain itU PER juga digunakan sebagai indikator perkembangan dan pertumbuhan suatu 
Widihartanto, et al/Jurnal Ekonomi Syariah Teori dan Terapan Vol. 5 No. 5 Mei 2018: 377-393; ANALISIS FAKTOR YANG MEMPENGARUHI TINGKAT INITIAL RETURN (STUDI PADA PERUSAHAAN NON KEUANGAN YANG TERMASUK DALAM INDEKS SAHAM SYARIAH INDONESIA YANG MELAKUKAN INITIAL PUBLIC OFFERING PADA TAHUN 2012-2016)

perusahaan di masa mendatang. Hartono (2009) menyatakan bahwa Price Earning Ratio menunjukkan rasio harga saham terhadap earning atau dengan kata lain menunjukkan berapa besar pemodal menilai harga saham terhadap kelipatan dari earning, Price Earning Ratio dapat dihitung mnggunakan rumus sebagai berikut:

Price Earning Ratio $=\frac{\text { Harga saham }}{\text { Laba bersih per Saham }}$ Perhitungan PER sangat penting karena rasio ini menjadi indikator penilaian perusahaan yang dapat digunakan untuk mengukur kemampuan pasar saham dalam menciptakan harga saham perusahaan terhadap kemampuan perusahaan dalam menciptakan laba per lembar saham.

\section{Prosentase Penawaran Saham}

Persentase kepemilikan yang ditahan oleh pemilik (insiders) menunjukkan adanya private information yang dimiliki oleh pemilik atau manajer (Leland \& Phyle dalam Gerianta, 2008). Pemegang saham lama akan tetap menginvestasikan modal pada perusahaannya apabila mereka yakin akan prospek pada masa mendatang. Pemegang saham lama tidak akan melepaskan proporsi kepemilikan saham bila mereka tidak yakin akan keberhasilan IPO sehingga proporsi kepemilikan saham yang ditahan oleh pemegang saham lama dapat dipertimbangkan sebagai faktor yang turut membangun keyakinan investor akan keberhasilan IPO perusahaan (Sulistio, 2005). Perusahaan dengan skala usaha yang besar dan tingkat pertumbuhan yang tinggi diharapkan akan memberikan tingkat keuntungan yang tinggi, maka akan menawarkan saham dengan nilai besar.

\section{Ukuran Perusahaan}

Ukuran perusahaan merupakan rata-rata penjualan bersih untuk tahun yang bersangkutan sampai beberapa tahun (Brigham dan Houston, 2001). Ukuran perusahaan dapat dinyatakan dalam total aktiva, penjualan dan kapitalisasi pasar. Semakin besar total aktiva, penjualan dan kapitalisasi pasar maka semakin besar pula ukuran perusahaan itu.

\section{Hubungan antar variabel}

\section{Hubungan ROE dengan tingkat initial return}

Semakin tinggi nilai ROE suatu perusahaan menandakan perusahaan tersebut mampu menghasilkan laba di masa yang akan datang dan laba merupakan informasi penting bagi investor sebagai bahan pertimbangan dalam menanamkan modalnya. Dengan tingginya nilai rasio ini kemungkinan investor untuk mendapatkan Initial return semakin tinggi, karena tingginya nilai ROE menandakan bahwa perusahaan tersebut mengalami profit. Maka hal tersebut menunjukkan bahwa ROE berpengaruh positif terhadap tingkat Initial return. Pernyataan tersebut sejalan dengan penelitian Yolana dan Martani (2005) mengungkapkan bahwa ROE 
Widihartanto, et al/Jurnal Ekonomi Syariah Teori dan Terapan Vol. 5 No. 5 Mei 2018: 377-393; ANALISIS FAKTOR YANG MEMPENGARUHI TINGKAT INITIAL RETURN (STUDI PADA PERUSAHAAN NON KEUANGAN YANG TERMASUK DALAM INDEKS SAHAM SYARIAH INDONESIA YANG MELAKUKAN INITIAL PUBLIC OFFERING PADA TAHUN 2012-2016)

berpengaruh signifikan positif dengan menaikkan nilai saham tersebut. Dengan tingkat Initial return.

\section{Hubungan antara DER dengan tingkat initial return}

Debt to Equity Ratio menunjukkan penggunaan hutang dalam rangka pembiayaan perusahaan, rasio ini mengukur seberapa jauh perushaan dibiayai oleh hutang. Semakin tinggi nilai DER menandakan struktur permodalan usaha lebih banyak memanfaatkan hutang - hutang relatif terhadap ekuitas. Semakin besar DER mencerminkan resiko perusahaan yang relatif tinggi, akibatnya para investor cenderung menghindari saham-saham yang memiliki nilai DER yang tinggi (Ang, 1997), karena perusahaan yang memiliki DER yang tinggi cendrung memberi return yang rendah sebab perusahaan akan berusaha melunasi hutangnya terlebih dahulu sebelum memberikan return pada investor. Penelitian Ardiansyah (2004) membuktikan bahwa DER berpengaruh pada Initial return setelah IPO.

\section{Hubungan antara TATO dengan tingkat initial return}

$$
\text { Total Asset Turnover (TATO) }
$$
menunjukkan kemampuan serta efisiensi perusahaan dalam memanfaatkanaktiva yang dimilikinya atau perputaran dari aktiva-aktiva tersebut. Semakin tinggi nilai TATO maka semakin efisien suatu perusahaan dalam memanfaatkan aktiva yang dimilikinya, hal tersebut akan menarik investor untuk berinvestasi di perusahaan tersebut sehingga akan demikian diduga bahwa semkin besar nilai TATO suatu perusahaan maka semakin besar pula tingkat Initial return.

\section{Hubungan antara PER dengan tingkat initial return}

Price Earning Ratio (PER) adalah rasio yang digunakan untuk mengukur seberapa tinggi para investor bersedia membayar atau menananmkan modal pada saham perusahaan. Para investor menggunakan PER sebagai pedoman dalam membeli saham, para investor lebih tertarik dengan saham perusahaan dengan tingkat PER rendah karena saham dengan nilai PER yang tinggi kemungkinan harga saham perusahaan tersebut tidak akan naik lagi yang berarti kemungkinan memperoleh capital gain akan lebih kecil dan itu berarti kemungkinan untuk mendapat initial return pun juga menjadi lebih kecil.

\section{Hubungan antara prosentase penawaran} saham dengan tingkat initial return

Perusahaan dengan skala usaha yang besar dan tingkat pertumbuhan yang tinggi diharapkan akan memberikan tingkat keuntungan yang tinggi, maka akan menawarkan saham dengan nilai besar. Demikian pula sebaliknya, perusahaan kecil yang baru berdiri dengan tingkat pertumbuhan usaha yang relatif lebih kecil , maka akan menawarkan saham dengan nilai kecil. Dengan demikian semakin besar prosentase penawaran saham maka makin besar pula pengharapan investor 
Widihartanto, et al/Jurnal Ekonomi Syariah Teori dan Terapan Vol. 5 No. 5 Mei 2018: 377-393; ANALISIS FAKTOR YANG MEMPENGARUHI TINGKAT INITIAL RETURN (STUDI PADA PERUSAHAAN NON KEUANGAN YANG TERMASUK DALAM INDEKS SAHAM SYARIAH INDONESIA YANG MELAKUKAN INITIAL PUBLIC OFFERING PADA TAHUN 2012-2016)

untuk menerima return. Dengan demikian

diduga semakin besar prosentase penawaran saham maka semakin besar Initial return, hal ini sejalan dengan penelitian sulistio (2005) yang menyatakan bahwa prosentase penawaran saham yang ditawarkan berpengaruh signifikan positif terhadap Initial return.

\section{Hubungan antara ukuran perusahaan dengan tingkat initial return}

Ukuran perusahaan merupakan cerminan dari total asset perusahaan, semakin besar total asset perusahaan, semakin besar pula ukuran perusahaan tersebut, Perusahaan berskala kecil memiliki tingkat ketidakpastian dimasa yang akan datang besar, sehingga tingkat resiko investasinya lebih besar dalam jangka panjang, begitu pula sebaliknya Dengan demikian diduga semakin besar ukuran perusahaan maka akan semakin besar Initial return yang di terima investor, pernyataan ini senada dengan hasil penelitian Trisnawati (1999) yang menyatakan bahwa ukuran perusahaan berpengaruh positif terhadap Initial return.

\section{Hipotesis}

1. Return on Equity, Debt to Equity Ratio, Total Asset Turnover, Price Earning Ratio, prosentase penawaran saham dan ukuran perusahaan memiliki pengaruh signifikan secara simultan terhadap Initial return.

2. Return on Equity, Debt to Equity Ratio, Total Asset Turnover, Price Earning Ratio, prosentase penawaran saham dan ukuran perusahaan memiliki pengaruh signifikan secara parsial terhadap Initial return.

\section{Model Analisis}

Model analisis dalam penelitian ini adalah: $Y=a+\beta 1 \times 1-\beta 2 \times 2+\beta 3 \times 3-\beta 4 \times 4+\beta 5 \times 5+$ $\beta 6 \times 6+e$

Keterangan:

$Y=$ Tingkat Initial return

$a=$ Koefisien konstanta

$1-5=$ Koefisien regresi variabel independen

$\begin{array}{ll}\mathrm{x} 1 & =\text { variabel ROE } \\ \mathrm{x} 2 & =\text { variabel DER } \\ \mathrm{x} 3 & =\text { variabel TATO } \\ \mathrm{x} 4 & =\text { variabel PER } \\ \mathrm{x} 5 & =\text { variabel prosentase saham yang } \\ \text { ditawarkan } & \\ \mathrm{x} 6 \quad=\text { variabel ukuran perusahaan } \\ \mathrm{e} \quad=\quad \text { Residual atau kesalahann } \\ \text { prediksi }\end{array}$

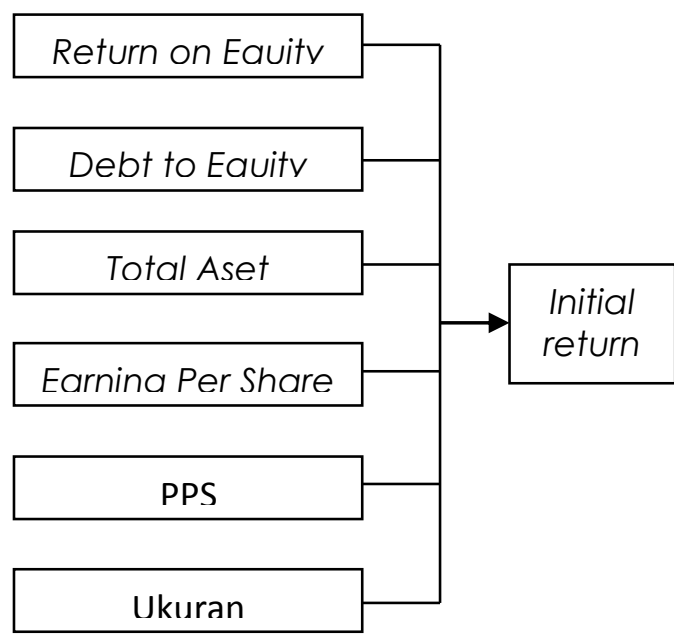

Gambar 1. Model Analisis

III. METODOLOGI PENELITIAN

Pendekatan yang digunakan dalam penelitian ini adalah pendekatan penelitian kuantitatif. Pendekatan ini 
Widihartanto, et al/Jurnal Ekonomi Syariah Teori dan Terapan Vol. 5 No. 5 Mei 2018: 377-393; ANALISIS FAKTOR YANG MEMPENGARUHI TINGKAT INITIAL RETURN (STUDI PADA PERUSAHAAN NON KEUANGAN YANG TERMASUK DALAM INDEKS SAHAM SYARIAH INDONESIA YANG MELAKUKAN INITIAL PUBLIC OFFERING PADA TAHUN 2012-2016)

menitikberatkan pada pengujian hipotesis,

Debt to Equity Ratio (DER)

yang nantinya menghasilkan kesimpulan yang dapat digeneralisasikan.

\section{Identifikasi Variabel}

Ada dua jenis variabel yang digunakan yaitu variabel independen yang terdiri dari ROE, DER, TATO, PER, prosentase penawaran saham dan ukuran perusahan, serta variabel dependen yakni initial return.

\section{Definisi Operasional Variabel}

Definisi operasional variabel dalam penelitian ini adalah:

a. Initial return

Initial return yang mana adalah selisih positif antara harga saham di pasar sekunder dengan harga saham di pasar primer, Initial return dapat digambarkan dengan persamaan sebagai berikut:

$$
I R=\frac{\mathrm{P} 1-\mathrm{P} 0}{\mathrm{P} 0} 100 \%
$$

Keterangan :

$\mathrm{IR}=$ Initial return

Pl = Harga saham di pasar sekunder

PO = Harga saham di pasar primer

Daftar harga saham perdana perusahaan yang melakukan IPO pada tahun 20122016 dan harga penutupan saham di hari pertama pada pasar sekunder dapat diperoleh dari IDX.

b. Return on Equity (ROE)

Informasi tentang ROE dapat dilihat dalam prospektus yang di terbitkan oleh perusahaan . ROE dapat dihitung dengan rumus sebagai berikut.

$$
\text { ReturnOnEquity }=\frac{\text { Laba Bersih }}{\text { Ekuitas }}
$$

c. Debt to Equity Ratio (DER)

menunjukkan kemampuan perusahaan dalam memenuhi seluruh kewajiban baik kewajiban jangka panjang maupun kewajiban jangka pendek. DER dapat dihitung dengan rumus sebagai berikut:

$$
\text { DebttoEquityratio }=\frac{\text { Total Debt }}{\text { Total Equity }}
$$

d. Total Asset Turnover (TATO)

Total Asset Turnover (TATO) menunjukkan kemampuan serta efisiensi perusahaan tersebut dalam menggunakan seluruh aktiva dalam menghasilkan volume penjualan tertentu. TATO dapat dihitung dengan rumus sebagai berikut

$$
\text { TotalAssetTurnover }=\frac{\text { Nett Sales }}{\text { Total Assets }}
$$

e. Price Earning Rario (PER)

Price Earning Ratio (PER) adalah rasio yang digunakan untuk mengukur seberapa tinggi para investor bersedia membayar atau menananmkan modal pada saham perusahaan, Price Earning Ratio (PER) dapat dihitung menggunakan rumus sebagai brikut:

Price Earning Ratio $=\frac{\text { Harga Saham Perdana }}{\text { Laba Bersih per Saham }}$

f. Prosentase saham yang ditawarkan

Prosentase saham yang ditawarkan menunjukkan prosentase saham yang ditawarkan kepada publik dalam pelaksanaan penawaran umum perdana atau IPO.

g. Ukuran perusahaan.

Ukuran perusahaan merupakan total asset yang dimiliki perusahaan, semakin besar total aset perusahaan 
Widihartanto, et al/Jurnal Ekonomi Syariah Teori dan Terapan Vol. 5 No. 5 Mei 2018: 377-393; ANALISIS FAKTOR YANG MEMPENGARUHI TINGKAT INITIAL RETURN (STUDI PADA PERUSAHAAN NON KEUANGAN YANG TERMASUK DALAM INDEKS SAHAM SYARIAH INDONESIA YANG MELAKUKAN INITIAL PUBLIC OFFERING PADA TAHUN 2012-2016)

maka semakin besar ukuran perusahaan

3. Perusahaan yang mengalami tersebut. ukuran perusahaan dapat dilihat melalui total aktiva dari laporan keuangan perusahaan pada tahun terahir sebelum perusahaan melakukan IPO.

underpriced pada hari pertama di pasar sekunder.

Sampel dalam penelitian ini ditentukan dengan menggunakan metode non probability sampling secara purposive sampling.

prosentase penawaran saham dan ukuran perusahaan dapat diperoleh dari laporan kevangan masing masing perusahaan.

\section{Jenis dan sumber data}

Jenis data yang digunakan dalam penelitian ini adalah data sekunder yang berupa laporan keuangan dan laporan tahunan perusahaan yang terdaftar pada Indeks Saham Syariah Indonesia yang melakukan IPO pada tahun 2012-2016. Data sekunder dalam penelitian ini diperoleh dari prosprktus yang diterbitkan oleh masing-masing perusahaan dan situs website Bursa Efek Indonesia, Yahoo finance, website e bursa (www.e-bursa.com).

\section{Populasi dan sampel}

Populasi penelitian ini memiliki kriteria sebagai berikut:

1. Perusahaan yang IPO dan terdaftar dalam Indeks Saham Syariah Indonesia diluar perusahaan perbankan dan lembaga keuangan pada tahun 20122016.

2. Terdapat data harga perdana perusahaan yang melakukan IPO dan harga penutupan saham di hari pertama pasar sekunder.

\section{Teknik analisis}

Teknik analisis yang digunakan dalam penelitian ini adalah regresi linier berganda.Penggunaan teknik analisis ini untuk mengetahui pengaruh variabel bebas terhadap variabel terikat secara simultan dan parsial. Berikut adalah teknikanalisis yang dilakukan:

1. Uji Normalitas, untuk mengetahui apakah data yang digunakan terdistribusi normal atau tidak. Melalui grafik P-P Plot.

2. Regresi linier Berganda, untuk melihat hubungan secara simultan antara variabel bebas dengan variabel terikat, serta menentukan sifat hubungan tersebut.

3. Uji Autokorelasi, untuk melihat apakah ada korelasi antar variabel gangguan pada satu penelitian dengan penelitian lain.

4. Uji Multikolinearitas, untuk mengetahui apakah terdapat korelasi antar variabel bebas. Dilakukan dengan melihat nilai VIF dan Tolerance.

5. Uji Heteroskedastisitas, untuk mengetahui apakah terdapat ketidaksamaan variance pada satu penelitian dengan penelitian lain. Dilihat melalui grafik Scatter Plot. 
Widihartanto, et al/Jurnal Ekonomi Syariah Teori dan Terapan Vol. 5 No. 5 Mei 2018: 377-393; ANALISIS FAKTOR YANG MEMPENGARUHI TINGKAT INITIAL RETURN (STUDI PADA PERUSAHAAN NON KEUANGAN YANG TERMASUK DALAM INDEKS SAHAM SYARIAH INDONESIA YANG MELAKUKAN INITIAL PUBLIC OFFERING PADA TAHUN 2012-2016)

6. Uji Koefisien Determinasi Berganda, untuk mengetahui besar pengaruh variabel bebas terhadap variabel terikat.

7. Uji F, untuk melihat apakah secara simultan variabel bebas berpengaruh signifikan terhadap variabel terikat.

8. Uji t, untuk melihat apakah secara parsial variabel bebas berpengaruh signifikan terhadap variabel terikat.

\section{HASIL DAN PEMBAHASAN}

\section{Uji Normalitas}

Hasil uji normalitas yang dilakukan dalam penelitian ini adalah sebagai berikut:

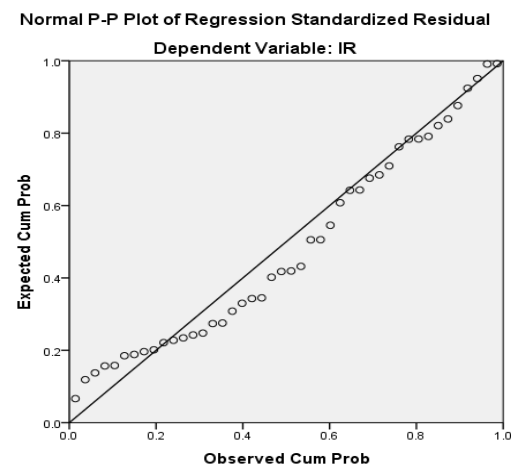

Sumber: Data diolah

Gambar.2

Berdasarkan grafik P-P Plot tersebut menunjukkan bahwa titik-titik menyebar di sekitar garis diagonal, maka dapat disimpulkan bahwa data yang digunakan dalampenelitian ini telah terdistribusi secara normal.

\section{Analisis Regresi Linier Berganda}

Hasil analisis regresi linier berganda yang dilakukan dalam penelitian ini adalah sebagai berikut:

Tabel 2
Analisis Regresi Linier Berganda ROE, DER, TATO, PER, PPS, SIZE Terhadap IR

\begin{tabular}{|rr|r|r|}
\hline \multicolumn{2}{|l|}{ Model } & \multicolumn{2}{|c|}{ Unstandardized Coefficients } \\
\cline { 3 - 4 } & & \multicolumn{1}{|c|}{$\mathrm{B}$} & \multicolumn{1}{c|}{ Std. Error } \\
\hline 1 & (Constant) & .605 & .468 \\
& ROE & .002 & .048 \\
& DER & -.003 & .005 \\
TATO & -.015 & .034 \\
PER & $7.615 \mathrm{E}-5$ & .000 \\
PPS & -.001 & .002 \\
SIZE & -.015 & .016 \\
\hline
\end{tabular}

Sumber: Data diolah

Berdasarkan hasil pengujian analisis regresi linear berganda pada Tabel diatas, maka didapatkan persamaan regresi sebagai berikut:

$Y=0.605+0.002(X 1)-0.003(X 2)-$

$0.015(X 3)+7.615 E-5(X 4)-0.001(X 5)-$

$0.015(X 6)+e$

Nilai konstanta sebesar 0.605 menunjukkan apabila variabel Return on Equity, Debt to Equity Ratio, Total Asset Turnover, Price Earning Ratio, prosentase penawaran saham dan ukuran perusahaan besarnya nol atau konstan, maka nilai nilai Initial return adalah sebesar 0.605, Koefisien regresi Return on Equity sebesar 0.002. Koefisien Debt to Equity Ratio memiliki nilai sebesar -0.003. Koefisien Total Asset Turnover memiliki nilai sebesar -0.015 . Price Earning Ratio memiliki nilai sebesar 7.615E5. Koefisien prosentase penawaran saham memiliki nilai sebesar -0.001 . Koefisien ukuran perusahaan memiliki nilai sebesar 0.015 .

\section{Uji Autokorelasi}


Widihartanto, et al/Jurnal Ekonomi Syariah Teori dan Terapan Vol. 5 No. 5 Mei 2018: 377-393; ANALISIS

FAKTOR YANG MEMPENGARUHI TINGKAT INITIAL RETURN (STUDI PADA PERUSAHAAN NON KEUANGAN YANG TERMASUK DALAM INDEKS SAHAM SYARIAH INDONESIA YANG MELAKUKAN INITIAL PUBLIC OFFERING PADA TAHUN 2012-2016)

Berikut adalah hasil uji

autokorelasi yang dilakukan dalam penelitian ini:

Tabel 3

Uji Autokorelasi

\begin{tabular}{|c|c|c|}
\hline $\begin{array}{l}\text { Durbin- } \\
\text { Watson }\end{array}$ & \multicolumn{1}{|c|}{ Hasil } & Keterangan \\
\hline 1.870 & $\begin{array}{l}\text { DW berada pada } \\
\text { rentang }-2 \text { sampai }+2\end{array}$ & $\begin{array}{l}\text { Tidak terdapat } \\
\text { Autokorelasi }\end{array}$ \\
\hline
\end{tabular}

Sumber: Data diolah

Nilai DW tersebut menunjukkan nilai 1.870.Karena nilai DW berada pada rentang -2 sampai +2 , maka dapat dinyatakan bahwa tidak terdapat korelasi dalam antar variabel.

\section{Uji Multikolinieritas}

Berikut adalah hasil uji Multikolinieritas yang dilakukan dalam penelitian ini:

Tabel 4

Uji Multikolinieritas

\begin{tabular}{|c|c|c|}
\hline \multirow{2}{*}{ Variabel } & \multicolumn{2}{|c|}{ Colliniearity Statistic } \\
\cline { 2 - 3 } & Tolerance & VIF \\
\hline ROE & 0,773 & 1,293 \\
DER & 0,946 & 1,057 \\
TATO & 0,638 & 1,569 \\
PER & 0,893 & 1,120 \\
PPS & 0,724 & 1,381 \\
SIZE & 0,662 & 1,510 \\
\hline
\end{tabular}

Sumber: Data diolah

Menurut tabel di atas, nilai tolerance dan VIF yang sesuai dengan aturan pengujian SPSS yakni ketika nilai tolerance $>0,10$ dan nilai VIF < 10 maka dapat dinyatakan tidak ada multikolinearitas.

\section{Uji Heteroskedastisitas}

Berikut adalah hasil uji Heteroskedastisitas yang dilakukan dalam penelitian ini:

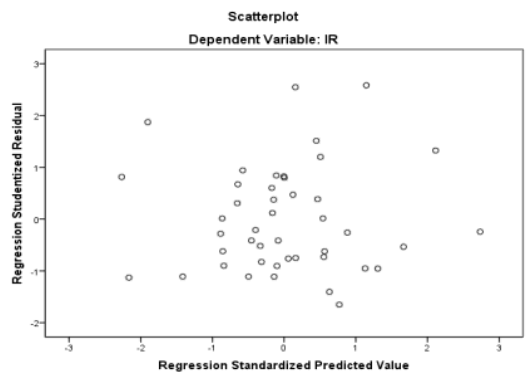

Sumber: Data diolah

Gambar 3

Berdasarkan grafik scatterplot pada gambar 4.2 terlihat bahwa titik-titik menyebar dan tidak membentuk pola tertentu, sehingga dapat disimpulkan bahwa model terbebas dari masalah heteroskedastisitas.

\section{Koefisien determinasi}

Berikut adalah hasil uji koefisien determinasi yang dilakukan dalam penelitian ini:

Tabel 5

Uji Koefisien Determinasi

\begin{tabular}{|c|l|}
\hline$R^{2}$ & \multicolumn{1}{|c|}{ Interpretasi Hasil } \\
\hline 0.059 & $\begin{array}{l}\text { Nilai R2 tersebut mengindikasikan bahwa } \\
\text { variabel bebas secara simultan dapat } \\
\text { menjelaskan variabel terikat sebesar 5,9\% }\end{array}$ \\
\hline
\end{tabular}

Sumber: Data diolah

Dari Tabel di atas dapat dilihat bahwa nilai $R^{2}$ yang di hasilkan dalam penelitian ini sebesar 0.059 atau 5.9\%, artinya variabel ROE, DER, TATO, PER, prosentase penawaran saham dan ukuran perusahaan .dapat menjelaskan variabel dependen yaitu return saham sebesar $5,9 \%$ sedangkan sisanya sebesar $94,1 \%$ dijelaskan oleh variabel lain yang tidak dimasukkan ke dalam model regresi. 
Widihartanto, et al/Jurnal Ekonomi Syariah Teori dan Terapan Vol. 5 No. 5 Mei 2018: 377-393; ANALISIS

FAKTOR YANG MEMPENGARUHI TINGKAT INITIAL RETURN (STUDI PADA PERUSAHAAN NON KEUANGAN YANG TERMASUK DALAM INDEKS SAHAM SYARIAH INDONESIA YANG MELAKUKAN INITIAL PUBLIC OFFERING PADA TAHUN 2012-2016)

Uji Hipotesis

Uji F

Berikut ini adalah hasil uji $F$ untuk mengetahui pengaruh variabel bebas terhadap variabel terikat secara simultan.

Tabel 6

Hasil Uji F

\begin{tabular}{|rl|r|r|r|}
\hline \multicolumn{1}{|c|}{ Model } & \multicolumn{1}{c|}{ df } & F & Sig. \\
\hline 1 & Regression & 6 & .390 & $.881^{\mathrm{a}}$ \\
& & & & \\
Residual & 37 & & \\
& Total & 43 & & \\
\hline
\end{tabular}

Sumber: Data Diolah

Berdasarkan hasil Uji F yang ada pada tabel 4.15, maka dapat diperoleh nilai $F$ sebesar 0.390 dengan tingkat signifikansi pengujian sebsar 0.881 . sgnifikansi uji $F$ lebih besar dari tingkat a yang telah ditentukan yaitu 0,05 dengan demikian hasil uji $\mathrm{F}$ menunjukkan bahwa $\mathrm{HO}$ diterima $\mathrm{HI}$ ditolak sehingga dapat disimpulkan variabel ROE, DER, TATO, PER, prosentase penawaran saham dan ukuran perusahaan memiliki pengaruh yang tidak signifikan terhadap Initial return secara simultan.

Uji $\uparrow$

Berikut ini adalah hasil uji $†$ untuk mengetahui pengaruh variabel bebas terhadap variabel terikat secara parsial.

Tabel 7

Hasil Uji $\uparrow$

\begin{tabular}{|ll|r|r|}
\hline \multicolumn{1}{|c|}{ Model } & \multicolumn{1}{c|}{$\mathrm{t}$} & \multicolumn{1}{c|}{ Sig. } \\
\hline $1 \quad$ (Constant) & 1.294 & .204 \\
ROE & .037 & .971 \\
DER & -.677 & .503 \\
& TATO & -.437 & .665 \\
\hline
\end{tabular}

\begin{tabular}{|l|l|l|}
\hline PER & .676 & .503 \\
PPS & -.340 & .735 \\
SIZE & -.945 & .351 \\
\hline
\end{tabular}

Sumber: Data diolah

Berdasarkan hasil uji † yang tertera pada Tabel diatas maka dapat dijelaskan pengujian setiap variabel independen terhadap variabel dependen sebagai berikut:

1. ROE: HO diterima,artinya secara parsial ROE berpengaruh tidak signifikan terhadap initial return.

2. DER: HO diterima, artinya secara parsial DER berpengaruh tidak signifikan terhadap initial return.

3. TATO: HO diterima, artinya secara parsial TATO berpengaruh tidak signifikan terhadap initial return.

4. PER: HO diterima, artinya secara parsial PER berpengaruh tidak signifikan terhadap initial return.

5. Prosentase penawaran saham: HO diterima,artinya secara parsial prosentase penawaran saham berpengaruh tidak signifikan terhadap initial return.

6. Ukuran Perusahaan: HO diterima, artinya secara parsial ukuran perusahaan berpengaruh tidak signifikan terhadap initial return.

\section{Pembahasan}

Pengaruh ROE, DER, TATO , PER, prosentase penawaran saham dan ukuran perusahaan Secara simultan Terhadap Initial return

Secara simultan ROE, DER, TATO, PER, prosentase penawaran saham dan 
Widihartanto, et al/Jurnal Ekonomi Syariah Teori dan Terapan Vol. 5 No. 5 Mei 2018: 377-393; ANALISIS FAKTOR YANG MEMPENGARUHI TINGKAT INITIAL RETURN (STUDI PADA PERUSAHAAN NON KEUANGAN YANG TERMASUK DALAM INDEKS SAHAM SYARIAH INDONESIA YANG MELAKUKAN INITIAL PUBLIC OFFERING PADA TAHUN 2012-2016)

ukuran perusahaan berpengaruh tidak signifikan terhadap Initial return. Hasil ini kemungkinan disebabkan pada periode penelitian (2011 - 2016) para investor lebih cenderung melakukan kegiatan trading daripada investasi murni sehingga para investor lebih memilih menggunankan analisis teknikal dari pada analisis fundamental sebagi pertimbangan dalam mengambil keputusan investasi.Faktor lain yang membuat informasi keuangan dan non keuangan tidak berpengaruh terhadap initial return adalah karena ketidak percayaan investor pada informasi yang ada pada prospektus, investor menduga perusahaan telah melakukan rekayasa informasi pada prospektus, sehingga kinerja perusahaan tersebut terlihat baik. Penelitian yang dilakukan Misnen (2003) menemukan bahwa manajemen laba dilakukan pada periode 2 tahun sebelum IPO. Sedangkan Saiful (2002) menemukan bahwa perusahaan yang akan melakukan IPO melakukan praktek manajemen laba untuk membentuk persepsi investor yang positif terhadap perusahaan. Selain itu kondisi makro ekonomi Indonesia pada priode 2012 - 2016 diduga juga turut mempengaruhi hasil penelitian ini.

\section{Pengaruh ROE Terhadap Initial return}

Secara parsial ROE berpengaruh tidak signifikan terhadap initial return. Tidak signifikannya pengaruh ROE ini di perkuat dengan penelitian Handayani (2008) yang menyatakan bahwa variabel Return on Equity secara parsial tidak menunjukkan pengaruh terhadap initial return perusahaan non keuangan yang IPO dan termasuk dalam Bursa Efek Jakarta pada periode 2000 - 2006. Salah satu faktor yang menyebabkan ROE berpengaruh tidak signifikan terhadap initial return adalah karena diduga kini para investor tidak lagi menggunakan ROE namun menggunakan ROA sebagai bahan pertimbangan dalam mengambil keputusan investasi, karena ROE hanya memperlihatkan efisiensi perusahaan dalam menggunakan modal sendiri tanpa memasukkan unsur hutang pada perhitungan efisiensi, berbeda dengan ROA yang memperlihatkan efisiensi perusahaan dalam menggunakan seluruh asetnya termasuk hutang - hutangnya. Selain itu investor menduga bahwa laporan keuangan yang ada dalam pros pektus telah mengalami manajemen laba sehingga kinerja perusahaan yang akan melakukan IPO terlihat bagus, dengan demikian ROE yang tersaji dalam proospektus tidak begitu diperhatikan investor.

\section{Pengaruh DER Terhadap Initial return}

Secara parsial DER berpengaruh tidak signifikan terhadap initial return. Hasil penlitian ini sesuai dengan beberapa penelitian terdahulu yang dilakukan oleh Ardiansyah (2004), Waludianti (2007), Handayani (2008), yang mana semua penelitian tersebut menyatakan bahwa Debt to Equity Ratio tidak berpengaruh signifikan terhadap initial return.Faktor yang menyebabkan Debt to Equity Ratio 
Widihartanto, et al/Jurnal Ekonomi Syariah Teori dan Terapan Vol. 5 No. 5 Mei 2018: 377-393; ANALISIS FAKTOR YANG MEMPENGARUHI TINGKAT INITIAL RETURN (STUDI PADA PERUSAHAAN NON KEUANGAN YANG TERMASUK DALAM INDEKS SAHAM SYARIAH INDONESIA YANG MELAKUKAN INITIAL PUBLIC OFFERING PADA TAHUN 2012-2016)

tidak berpengaruh signifikan terhadap initial return karena investor memandang besarnya nilai Debt to Equity Ratio tidak hanya dipengaruhi kinerja manajemen saja melainkan juga dipengaruhi oleh faktor di luar perusahaan misalnya seperti krisis moneter, inflasi, kenaikan tingkat suku bunga dan kebijakan pemerintah.

\section{Pengaruh TATO Terhadap Initial return}

Secara parsial TATO berpengaruh tidak signifikan terhadap initial return. Hasil penelitian ini sesuai dengan penelitian Manao \& Deswin (2001) yang menyatakan bahwa Total Asset Turnover tidak berpengaruh terhadap initial return.Penyebab Total Asset Turnover berpengaruh tidak signifikan terhadap initial return karena investor beranggapan bahwa informasi perputaran aktiva tidak dapat dijadikan patokan untuk menunjukkan efisiensi perusahaan dalam memanfaatkan aktivanya, selain itu investor juga beranggapan bahwa informasi tentang Total Asset Turnover yang ada pada prospektus telah di mark up sehingga perusahaan tersebut terlihat efisien dalam mengelola asset - asetnya, sehingga informasi nilai Total Asset Turnover kurang di perhatikan investor dalam berinvestasi di pasar modal.

\section{Pengaruh PER Terhadap Initial return}

Secara parsial PER berpengaruh tidak signifikan terhadap initial return. Hasil penelitin ini sesuai dengan penelitian yang dilakukan oleh Sulistio (2005) yang berpendapat bahwa variabel Price Earning Ratio tiidak berpengaruh signifikan

terhadap initial return. Faktor yang menyebabkan PER berpengaruh tidak signifikan terhadap initial return diduga karena kini investor tidak lagi menggunakan perhitungan PER melainkan menggunakan Price to Earning Growth (PEG), investor beranggapan bahwa untuk menganalisa masa depan suatu saham lebih cocok untuk menggunakan Price to Earning Growth karena PER hanya memberikan gambaran valuasi di masa sekarang tanpa memperhatikan valuasi di masa depan.

\section{Pengaruh Prosentase Penawaran Saham} Terhadap Initial return

Secara parsial prosentase penawaran saham berpengaruh tidak signifikan terhadap initial return. Hasil penelitian ini sejalan dengan penelitian Gumanti (2007) dan Handayani (2008) yang menyatakan bahwa proosentase penawaran saham tidak berpengaruh signifikan terhadap initial return. Penybab prosentase penawaran saham berpengaruh tidak signifikan terhadap initial return dimungkinkan karena pada saat membeli saham para investor tidak berorientasi pada jumlah saham yang ditawarkan, melainkan seberapa besar nilai penawaran saham tersebut, karena harga sahamlah yang menentukan tingkat keuntungan. Motivasi terhadap capital gain inilah yang menyebabkan para investor cenderung tidak memperhatikan informasi tentang 
Widihartanto, et al/Jurnal Ekonomi Syariah Teori dan Terapan Vol. 5 No. 5 Mei 2018: 377-393; ANALISIS FAKTOR YANG MEMPENGARUHI TINGKAT INITIAL RETURN (STUDI PADA PERUSAHAAN NON KEUANGAN YANG TERMASUK DALAM INDEKS SAHAM SYARIAH INDONESIA YANG MELAKUKAN INITIAL PUBLIC OFFERING PADA TAHUN 2012-2016)

prosentase penawaran saham sebagi pertimbangan dalam keputusan investasi.

Pengaruh Ukuran Perusahaan Terhadap Initial return

Secara parsial ukuran

ISSI, yang melakukan IPO pada periode (2012 - 2016).

2. Return on Equity (ROE), Debt to Equity Ratio (DER), Total Asset Turnover (TATO), Price Earning Ratio (PER), prosentase penawaran saham dan ukuran perusahaan secara parsial berpengaruh tidak signifikan terhadap Initial return perusahaan non keuangan yang termasuk dalam ISSI, yang melakukan IPO pada periode (2012 - 2016).

\section{DAFTAR PUSTAKA}

Ang, Robert, 1997. Buku Pintar Pasar Modal Indonesia. Mediasoft Indonesia.

Anoraga, Pandji, dan Pakarti Piji. 2001. Pengantar pasar modal. Edisi Revisi. PT Asdi Mahasatya. Jakarta. aset yang dimiliki oleh perusahaan bila tidak dikelola dengan baik oleh suatu perusahaan untuk kegiatan oprasi suatu perusahaan, maka tidak akan dapat menghasilkan laba yang besar. Laba yang tidak maksimal akan membuat harga saham menurun.

\section{KESIMPULAN}

Berdasarkan penelitian yang telah dilakukan, maka dapat diambil kesimpulan sebagai berikut

1. Return on Equity (ROE), Debt to Equity Ratio (DER), Total Asset Turnover (TATO), Price Earning Ratio (PER), prosentase penawaran saham dan ukuran perusahaan secara simultan berpengaruh tidak signifikan terhadap Initial return perusahaan non keuangan yang termasuk dalam 
Widihartanto, et al/Jurnal Ekonomi Syariah Teori dan Terapan Vol. 5 No. 5 Mei 2018: 377-393; ANALISIS

FAKTOR YANG MEMPENGARUHI TINGKAT INITIAL RETURN (STUDI PADA PERUSAHAAN NON KEUANGAN YANG TERMASUK DALAM INDEKS SAHAM SYARIAH INDONESIA YANG MELAKUKAN INITIAL PUBLIC OFFERING PADA TAHUN 2012-2016)

Dahlan, Siamat. 2010. Manajemen Lembaga Keuangan, "Kebijakan Moneter dan Perbankan",Jakarta : Fakultas Ekonomi Universitas Indonesia.

Daljono , 2000 , "Analisis Faktor-faktor yang Mempengaruhi Initial return Saham yang Listing di BEJ Tahun 1990 1997", Simposium Nasional Akuntansi III , IAI, September.

Firdaus, Muhammad. 2004. Ekonometrika Suatu Pendekatan Aplikatif. Jakarta: Bumi Aksara.

Gerianta, Wirawan Yasa. 2008. Penyebab Underpricing Pada Penawaran Saham Perdana di Bursa Efek Indonesia. Jurnal Akuntansi dan Bisnis, Vol 3.

Gujarati, Damodar N. 2003. Ekonometrika Dasar. Terjemahan oleh Sumarno Zain.2007. Jakarta : Erlangga.

Gumanti, TA. 2003. Earning Management Dalam Penawaran Saham Perdana di Bursa Efek Jakarta, Simposium Nasional Akuntansi III, IAI.

Hanafi, Mamduh M dan Abdul Halim, 2005. Analisis Laporan Kevangan, Edisi Kedua, Yogyakarta : STIE YKPN.

Handayani, Sri Retno. 2008. Analisis Faktorfaktor yang Mempengaruhi Underpricing pada Penawaran Umum Perdana (Studi Kasus pada Perusahaan Keuangan yang Go Publik di Bursa Efek Jakarta Tahun 2000-2006).Tesis.

Semarang:
Magister Manajemen, Universitas Diponegoro.

Husnan, Suad , 2009 , Teori Portfolio \& Analisis Sekuritas, UPP AMP YKPN, Yogyakarta.

Jogianto, Hartono, 2009 , Teori Portfolio dan Analisis Investasi, BPFE UGM, Yogyakarta.

Manao, Hekinus dan Nur Deswin. 2001. "Asosiasi Rasio Keuangan dengan Return Saham: Pertimbangan Ukuran Perusahaan Serta Pengaruh Krisis Ekonomi di Indonesia". Simposium Nasional Akuntansi IV. IAI. Oktober.

Syamsudin, Lukman. 2010. Manajemen Keuangan Perusahaan, Konsep Aplikasi dalam Persencanaan, Pengawasan, dan Pengambilan Keputusan (Edisi Baru). Penerbit PT Raja Grafindo Persada. Jakarta.

Trisnawati, Rina , 1999 , "Pengaruh Informasi Prospektus pada Return Saham di Pasar Modal", Simposium Nasional Akuntansi II , IAI , September.

Weston J. Fred dan Eugene F. Brigham. 1993. Dasar-dasar Manajemen Keuangan, Jilid 2, Edisi Kesembilan, Terjemahan oleh Alfonsus Sirait, Jakarta: Erlangga

Yolana, Chastina dan Dwi Martani. 2005. Variabel-Variabel yang Mempengaruhi Fenomena Underpricing pada Penawaran Saham Perdana di Bursa Efek Jakarta tahun 1994-2001. Simposium Nasional Akuntansi VIII. 